Sepielak, K. (2014). Translation techniques in voiced-over multilingual feature movies. Linguistica Antverpiensia, New Series. Themes in Translation Studies, 13, 251-272.

\title{
Translation techniques in voiced-over multilingual feature movies ${ }^{1}$
}

\section{Katarzyna Sepielak}

Department of Translation and Interpreting and East Asian Studies, Autonomous University of Barcelona / TransMedia Catalonia, Spain sepielak@gmail.com

This paper maps out the use of translation techniques used for multilingual interactions in voiced-over movies. First, the present study aims to determine how multilingual elements are introduced into the films and what implications these elements carry. Secondly, qualitative analysis is used in view of showing which particular translation techniques are employed to transfer multilingual elements in voiced-over translation. Four multilingual movies available with Polish voiced-over soundtrack on DVD were selected: Vicky Cristina Barcelona (directed by Woody Allen, 2008), Nine (Rob Marshall, 2009), Avatar (James Cameron, 2009), and Inglourious Basterds (Quentin Tarantino, 2009). The analysis enabled us to distinguish a type of translation technique which has never been described before: exposition, which in the case of multilingual movies might constitute an efficient tool for recreating the presence of multilingual environment. The results also reveal that translation techniques used to translate multilingual elements do not significantly differ from those used when approaching L1 (main language of the source text) elements. However, the effect they can have on multilingualism might be completely different from that intended when translating $L 1$.

\section{Introduction}

Multilingual audiovisual texts are part of our modern and globalised world, with its co-existence of languages and cultures. Although, according to Heiss (2004), "traces of the phenomenon of multilingualism, or at least code mixing and code switching, have always been present, not only in European but also in Hollywood films" (p. 209), deeper and more systematic research into this particular phenomenon in Audiovisual Translation Studies has still to be conducted. Language in a movie may have an important function; according to Wahl (2005), when "examining the history of sound film, one can easily find examples where language itself as a semiotic system is part of the message of the film and not only a vehicle of content" (p. 1). For this reason, it is very interesting to 
examine how multilingualism travels from the original text into the translated one.

The objective of this paper is to present the use of translation techniques used for multilingual interactions in a number of Polish voiced-over movies. First, this study aims to determine how multilingual elements are introduced into the films and what implications these elements carry. Secondly, qualitative analysis is used in view of mapping out the translation techniques which are employed to transfer multilingual elements in voiced-over movies. The choice of films to study was based primarily on the presence of several languages in the movies; that is, apart from the main original language (L1), English, and the translated language (L2), Polish, the film should also contain dialogues in one or more other languages (L3). The selection was refined to comprise four films: Nine (directed by Rob Marshall, 2009), Vicky Cristina Barcelona (Woody Allen, 2008), Avatar (James Cameron, 2009) and Inglourious Basterds (Quentin Tarantino, 2009). Three genres are represented: drama, science-fiction and adventure (genre categorisation based on the Internet Movie Database, commonly known as IMDb, n.d.). Although Woody Allen's Vicky Cristina Barcelona had its world premiere in 2008, it was not released in Poland until 17 April 2009 ("Filmweb", n.d.).

Before presenting the analysis and its results, I first discuss multilingualism and translation techniques.

\section{Multilingualism in audiovisual translation}

According to Grutman (1998), "every text that contains at least one foreign word can be identified as multilingual" (p. 157). This definition of multilingual texts allows for a vast spectrum of degrees of multilingualism; however, I believe that what matters most is the function multilingualism performs within each film. It can be assumed that the correlation between the number of L3 elements and the function of multilingualism in the text is directly proportional. In other words, the bigger the role played by multilingualism in the movie, the more L3 insertions appear. Therefore, establishing the implications of L3 elements in the movie would seem to be the first step in the translation process.

On the one hand, just as in the case of literature, where multilingualism may be used as a "mimetic device used to give the reader a flavor of the author's heritage language" (Baldo, 2009, "para." 2), multilingualism in films can also reveal the characters' mother tongue. In this case, the elements play a rather passive role, without setting in motion further connotations, as in Nine, where Italian (L3) seems to act as a reminder of the setting of the movie. On the other hand, multilingualism also contributes to creating a credible reality by portraying the identity of a group (Martins, 2005) with the associated emotional and connotative baggage. This function becomes active by providing general, and often 
stereotypical, assumptions about a particular group. The viewer recalls this knowledge in order to get a better understanding of some of the actions or ways of thinking of the characters in the group. In this case the multilingual elements perform a very significant role that complements the psychological dimension of characters. This can be observed in Vicky, Cristina, Barcelona, where the Spanish language and Spanish setting activate the stereotype of the Latin lover.

As Meylaerts (2006) points out, translating multilingual texts "has become a research issue [...], however, more often than not, analyses are conducted in terms of 'difficulties', of 'problems', of 'untranslatability'" (pp. 4-5). Nevertheless, some attempts (such as those of Bartoll, 2006; Corrius i Gimbert, 2008; Delabastita \& Grutman, 2005; Meylaerts, 2006; Corrius \& Zabalbeascoa, 2011) have been made to present a gamut of useful techniques for dealing with multilingual movies. Scholars who have studied multilingualism in audiovisual texts have thus far mainly dealt with dubbing and subtitling. To the best of my knowledge, no study on voiced-over multilingual movies has yet been carried out, probably due to the fact that the voice-over mode is hardly ever used in fictional films, except in countries such as Poland, Russia, Latvia, Lithuania and Estonia.

Christine Heiss (2004), a pioneer in the study of dubbed multilingual film, suggests using a multiplicity of modes (subtitling and dubbing) to translate multilingual film. According to her, the co-existence of dubbing (used to translate the main language of communication) and subtitles (for the other languages) could lead to a satisfying result. Heiss (2004) concludes that introducing subtitles in a dubbed version "would place greater demands on the audience but would correspond more closely to the cultural diversity presented in the film" (p. 216). This assumption is supported by Baldo (2009), who states that "subtitling alters the source text to the least possible extent and enables the target audience to experience its foreignness" (para. 2), whereas O'Sullivan (2011) points out a recent trend that consists of "both dubbing and subtitling in the translation of the same film" (p. 198).

However, while the solution of mixing dubbing and subtitling could work in countries that tend to dub their media, it is not an easy option for countries which traditionally favour subtitles. Writing about subtitles for the hard of hearing (SHD), Bartoll (2006) suggests "the use of different colors or the paratextual information within brackets" (p. 1) in order to mark the use of an additional language in the source text.

The discussion concerning how to translate multilingual movies, then, has been developing in the direction of dubbing and subtitling, leaving aside the voice-over transfer mode. This is not to say that voiceover has not been made the object of academic study (see, for example, Aleksonyté, 1999; Chaume, 2004; Franco, Matamala \& Orero, 2010; Grigaraviciute \& Gottlieb, 1997; Orero, 2006; Skuggevik, 2009). The literature concentrates on two main limitations of the voice-over mode: 
(1) the delay between the original and the translated soundtrack (Chaume, 2004), and (2) one voice-artist overlaying all actors of the original soundtrack (Skuggevik, 2009). In addition, in Poland, one male voiceartist generally reads all the dialogues; his delivery has to remain as monotonous as possible and it performs one function only: it conveys linguistic information, leaving aside most para-verbal components. It might be assumed, therefore, that those characteristic constraints for voice-over would result in different strategies and techniques, or at least in their distribution, than the one used in dubbing or subtitling.

\section{Translation techniques in audiovisual translation}

A valuable contribution towards analysing translation techniques is that by Gottlieb (1997), who identifies ten strategies used in subtitled movies (see Table 1 below). For the purposes of our analysis, the term "strategy" used by Gottlieb has been replaced with "technique" in order to maintain a differentiation between translation technique and translation strategy, which, according to Molina and Hurtado (2002), "occupy different places in problem solving: strategies are part of the process, techniques affect the result" (p. 507).

Table 1: Gottlieb's classification of translation techniques

\begin{tabular}{|l|l|}
\hline $\begin{array}{l}\text { Type of } \\
\text { technique }\end{array}$ & Character of translation \\
\hline Expansion & $\begin{array}{l}\text { Expanded expression, adequate rendering (culture-specific } \\
\text { references) }\end{array}$ \\
\hline Paraphrase & $\begin{array}{l}\text { Altered expression, adequate rendering (non-visualised } \\
\text { language-specific phenomena) }\end{array}$ \\
\hline Transfer & $\begin{array}{l}\text { Full expression, adequate rendering (neutral discourse, slow } \\
\text { tempo) }\end{array}$ \\
\hline Imitation & $\begin{array}{l}\text { Identical expression, equivalent rendering (proper nouns, } \\
\text { international greetings, etc.) }\end{array}$ \\
\hline Transcription & $\begin{array}{l}\text { Anomalous expression, adequate rendering (non-standard } \\
\text { speech) }\end{array}$ \\
\hline Dislocation & $\begin{array}{l}\text { Differing expression, adjusted content (musical or visualised } \\
\text { language-specific phenomena) }\end{array}$ \\
\hline Condensation & Condensed expression, concise rendering (normal speech) \\
\hline Decimation & $\begin{array}{l}\text { Abridged expression, reduced content (fast speech of some } \\
\text { importance) }\end{array}$ \\
\hline Deletion & $\begin{array}{l}\text { Omitted expression, no verbal content (fast speech of less } \\
\text { importance) }\end{array}$ \\
\hline
\end{tabular}


\begin{tabular}{l|l} 
Resignation & Differing expression, distorted content (untranslatable
\end{tabular} elements)

Gottlieb's classification was later used by Aleksonyte (1999), who applied the strategies to a comparative analysis of Danish subtitling and Lithuanian voice-over in the film Breaking the Waves. It was also used by Garcarz (2008) to conduct an analysis of slang in voiced-over fiction movies, which enabled the author to identify seven translation techniques: omission, functional equivalent, substitution, description, literal translation, neologisation, and compensation. Garcarz's proposal, however, does not take into consideration the co-existence of two (potentially complementary) soundtracks: the original (sometimes audible to the viewer) and the voiced-over one. In other words, Garcarz focuses only on the translated soundtrack, although in some cases the audience may also be exposed to the original soundtrack, which they might well understand.

To put it differently, aspects of multilingual movies and translation techniques have until very recently been considered as separate phenomena. Recent work by Corrius and Zabalbeascoa (2011, 2012) and Corrius (2008) bridges the two topics in a bid to analyse the multilingual elements (L3) in dubbed versions of films. Thus, Corrius and Zabalbeascoa (2011) map a detailed spectrum of solutions that might be applied to elements of L3 depending on its relation to other source text (ST) and target text (TT) features. They propose nine operations that might be conducted on the L3 elements of the source text, which range from deleting to adapting the L3 elements in the target text.

Corrius and Zabalbeascoa's taxonomy of translation techniques in multilingual movies would seem to be a very useful framework for resolving L3 constraints. However, as the classification is based on an analysis conducted on dubbed movies, it does not take into consideration the presence of the original soundtrack that might influence the solution adopted by the translator or, being audible, constitute the solution itself. For this reason, we have decided to use as a starting point the classification proposed by Gottlieb (1997), which appears to be the most complete one for the purposes of our research.

\section{Theory in practice - the analysis}

Despite the common denominator - the presence of multilingualism there are significant differences between the nature and function of the L3 in the four films we analysed; according to Corrius and Zabalbeascoa (2011), this might influence choices made in translation. Thus, the first step in our analysis is to determine how multilingual elements are used in the audiovisual texts, and to identify their function. 


\subsection{To be or not to be ... Italian - Nine}

The musical Nine is set in Italy and the storyline revolves around a famous Italian film director, Guido Contini, who at the age of 50 struggles in his professional life and is unable to write a script for a new movie. He tries to solve both his personal and his professional problems by analysing his dramatic relationships with women who have been important in his life. The multilingualism in the film takes a very specific form. The Italian context is introduced in a way that does not support the credibility of the story but instead only reminds the audience where the plot takes place. Multilingualism is then introduced in a very loose way, through several channels. The visual channel shows the Italian setting with stereotypical references such as cars, clothes and typical Italian landscapes. The acoustic channel is more intermingled. Although the movie is set in Italy and most of the characters are either Italian or French, they speak English with a strong Italian or French accent and interlay Italian or French words in their dialogues. Naturally, the strategy of enriching dialogues in the film with either Italian or French words must be based on the assumption that this will not hinder the audience's understanding. This assumption results from the phenomenon of language contact which, according to Bleichenbacher (2008), "occurs when speakers of different languages interact" (p. 8). The interaction, however, is not limited to personal contact but also refers to large-scale processes such as "territorial expansion (...), political unions, boarder contacts and migration (...)" (Bleichenbacher, 2008, p. 8). Such processes contribute to a better familiarity with different cultures. Interjections such as "Maestro", "Signori", "Grazie", "Bon giorno", "Dottore", "Si" and "Pronto" not only introduce the Italian context but are perfectly understandable to non-Italian spectators.

\subsection{We'll eat well, we'll drink good wine, we'll make love ... - Vicky Cristina Barcelona}

Owing to the Spanish setting of Vicky Cristina Barcelona, Woody Allen also uses multilingual elements in his movie. He presents a story of two American tourists, Vicky and Cristina, who decide to spend their holiday in Barcelona. They meet a seductive painter, Juan Antonio, who invites them on a trip to Oviedo, where they both fall in love with him. Despite her feelings to the contrary, Vicky decides to marry her fiancé, Doug, and Cristina moves in with Juan Antonio. After a while she meets his ex-wife, María Elena, and the three of them start a relationship. In the movie, there are many stereotypes, such as the American tourist and the Latin lover. Recreating clichés and stereotypes would not be as successful without a clear differentiation between nationalities. Indeed, language seems a very useful tool in marking stereotypes and also in portraying a situation as 
reality. The credibility of the communication between characters in the film is strengthened by Spanish insertions (e.g. “¿Cómo se dice?”), or by pointing directly to the language differences (e.g. "she doesn't understand Spanish").

\subsection{I hear you ...-Avatar}

James Cameron's Avatar tells the story of a paraplegic Marine, Jake Sully, who goes on a mission to the distant world of Pandora. There he meets Parker Selfridge, who wants to drive off the native humanoid people, the $\mathrm{Na}$ 'vi, in order to mine for the precious material scattered throughout their forest homeland. Jake is promised spinal surgery to heal his legs if he gathers useful information about the Na'vi. By using an avatar identity, Jake bonds with the native tribe and falls in love with Neytri, the daughter of the tribe's leader.

As the movie Avatar takes place on another planet, multilingualism has a completely different nature from that of the other three movies analysed in this article. An entire language, $\mathrm{Na}$ 'vi, was invented for the purposes of the film. The idea of using an invented language originated well before filming commenced. Paul Frommer, a professor from the University of Southern California and the creator of Na'vi language, explains that James Cameron had a vision of a language that would be characterised by:

[a] consistent sound system (phonology), word-building rules (morphology), rules for putting words together into phrases and sentences (syntax), and a vocabulary (lexicon) sufficient for the needs of the script. He [Cameron] also wanted the language to be pleasant sounding and appealing to the audience. (Frommer, 2009, para. 9)

The original version provided subtitles for many of the utterances in order to enable the viewer to understand the dialogue. The invented Na'vi language is then not only a mixture of unusual sounds that indicate an extraterrestrial world, but it also functions as a means of transferring the culture, traditions and beliefs of the Na'vi people. The Na'vi language was designed with the intention of giving more depth and an appearance of plausibility to the fictional world with which it is associated. Multilingualism clearly marks the line between humans and Na'vi people, but it is also a tool with which to present the Na'vi perspective within the movie. In order to comprehend the world of the Na'vi, Jake Sully has to learn their language. 


\subsection{The Babel of language - Inglourious Basterds}

Tarantino's Inglourious Basterds takes place in Nazi-occupied France during World War II. The movie is constructed around two plots. The first develops the story of a young Jewish refugee, Shosanna Dreyfus, who witnesses the slaughter of her family by SS Colonel Hans Landa. She manages to escape and flees to Paris, where she becomes the owner of a cinema. The second narrative strand is the story of a squad of JewishAmerican soldiers led by Lieutenant Aldo Raine, who kills and scalps Nazis. The two plots meet at the premiere of Dr. Josef Goebbels' propaganda film, which is held in Shoshanna's cinema.

The characters' nationality is directly reflected in the language, that is, Germans speak German, Americans and British speak English. The language itself, along with the characters' accents and body language, plays a crucial role in the plot. Tarantino (2009) explains that this meticulous procedure of introducing multilingualism should contribute to the credibility of the events. According to him:

[t]here have been certain contrivances, especially when it comes to language, where people are supposed to be speaking German, but they're speaking English ... and I just think that's a contrivance we've put up with for too long. (...) I think that day is over. ... When movies take place in Nazi Germany and they're all speaking in English, in particular almost Shakespearean English, you'd think the Third Reich started at the Old Vic. (Tarantino, 2009, para. 3)

It is therefore not surprising that language is an overarching part of every scene and defines the progression of events. Moreover, language seems to be a major theme in the movie. From the opening scene in which Colonel Landa interrogates a French dairy farmer about rumours he is hiding a Jewish family, the audience is shown that language influences the destiny of some of the film's characters. In this scene, Landa switches from French that he speaks very fluently to English, arguing falsely that his French is limited. In fact, this switching of language shows Landa's menacing strategy of interrogation. He assumes that the Jewish family does not speak English and is therefore unaware that the farmer has been pressed to betray them. They are finally shot by the Nazi soldiers.

However, knowledge of the enemy's language is not enough. The difference between life and death can also be made by accent and body language. A telling example of this occurs in the scene in the tavern in the village of Nadine. Lieutenant Hicox's strange accent attracts the attention of Major Hellstrom, which leads the major to investigate Hicox's ancestry. Although Hicox is able to convince Hellstrom to believe his cover story, he ultimately gives himself away by ordering three drinks and holding up the three fingers from the little finger to the index. As the survivor, Bridgett von Hammersmark, explains, when indicating three 
one should hold up the three fingers from thumb to index. The way Hicox indicated three was not German.

As discussed above, Tarantino's movie exploits several dimensions of multilingualism, ranging from knowledge of the language to accent, pronunciation and gesticulation. Moreover, it is not limited to isolated insertions but extends to whole conversations. The co-existence of English, French, German and Italian leads to the introduction of an interpreter in the film; the scenes with interpreters represent another direct challenge in the voice-over mode. It seems plausible to assume that the rapid and overlapping dialogues, the clear separation between characters and their languages, and the figure of an interpreter who facilitates communication between characters requires a specific translation approach.

\section{Methodology}

Taking into account the nature and function of multilingualism in movies, it is particularly interesting to analyse whether multilingualism transfers and, if it does, how it is maintained in voiced-over versions. In order to determine which translation techniques were used to translate multilingual elements, the present study resorts to the classification presented by Gottlieb (1997) (see section 3).

A preliminary analysis led us to distinguish an additional technique, that of "exposition", which we explain below. The need to introduce it to the taxonomy results from the difference between subtitles and voice-over characteristics. In subtitled films the audience is always exposed to the original soundtrack. In the case of multilingual movies, this is enormously advantageous as multilingual elements are heard and fulfil the function of providing both the exotic flavour and the clear differentiation of languages used by characters. However, in voiced-over movies the audience is exposed to two soundtracks: the original and, simultaneously, the translated one. Hence, the synchrony between the two soundtracks plays a significant role in this mode of transfer. By effectively synchronising the two soundtracks, the translated version would not provide any translation of a multilingual element. The original soundtrack would, however, still be entirely audible and in many cases understandable. Therefore, the audience will be exposed to the original soundtrack and have to rely on their understanding of the original dialogue, as in the following example from Nine, where Carla meets Guido at the railway station: 
Table 2: Exposition technique in the movie Nine (2009)

\begin{tabular}{|l|l|l|l|l|}
\hline \multirow{2}{*}{$\begin{array}{l}\text { TCR } \\
\text { original }\end{array}$} & Original version & Polish & \multicolumn{2}{|l|}{ Translation technique } \\
\cline { 4 - 5 } & version & Replica & $\begin{array}{l}\text { Multilingual } \\
\text { element }\end{array}$ \\
\hline 00:23:48 & $\begin{array}{l}\text { CARLA: } \\
\text { Guido! Ciao! }\end{array}$ & - & Exposition & Exposition \\
& & & & \\
\hline
\end{tabular}

This fragment was not translated into Polish. However, it cannot be said deletion is occurring here, as the whole utterance is perfectly audible and the Polish viewer encounters the same situation as the English viewer: he or she is exposed to the Italian flavour, and can easily identify the multilingual part and understand the greeting. The technique of using synchrony and leaving the original soundtrack perfectly audible with no translation provided will henceforth be labeled as "exposition".

Comparison of the utterances that contain a multilingual element (L3) between the original and the translated versions was conducted manually. As shown in the example below (Table 3), the data collected contain the time code record (TCR, column 1), the original utterance (column 2), the Polish voiced-over translation (column 3), the literal back translation (column 4), and the translation techniques employed (column 5). The data concerning the translation technique were analysed according to two units of analysis: the replica (macro unit) and the multilingual element (micro unit). For the purposes of analysis, any insertion, single word or expression in the third language (L3) is considered to be a multilingual element, whereas the concept of the replica is adapted from Merino Álvarez (2005), who defines it as a "minimal structural unit"”. According to Merino Álvarez (2005):

[b]eyond the use made of grammatical units or larger units (acts or scenes in theater, film scenes or sequences in a movie), the dramatic text is elaborated on the page, and also on stage and screen, as an exchange of replicas. In each of these we have, in general, the character's name, or discourse that belongs to him or her, together with the indications that surround the oral performance of the speech. (p. 3; my translation)

The unit of replica, introduced in AVT literature by Romero Ramos (2010), enables us to determine the translation techniques applied by the translator by comparing the original and the translated utterances while bearing in mind the visual channel and both audible soundtracks. The analysis also intends to show the combination of translation techniques, that is, the interdependence between these two different units. The 
multilingual elements in the utterance in the original and its translation into Polish are highlighted in bold.

Table 3: Data for the movie Vicky Cristina Barcelona

\begin{tabular}{|c|c|c|c|c|c|}
\hline \multirow{2}{*}{$\begin{array}{l}\text { TCR } \\
\text { original }\end{array}$} & \multirow{2}{*}{$\begin{array}{l}\text { Original } \\
\text { version }\end{array}$} & \multirow{2}{*}{$\begin{array}{l}\text { Polish } \\
\text { version }\end{array}$} & \multirow{2}{*}{$\begin{array}{l}\text { Back } \\
\text { translation }\end{array}$} & \multicolumn{2}{|c|}{ Translation technique } \\
\hline & & & & Replica & $\begin{array}{l}\text { Multilingual } \\
\text { element }\end{array}$ \\
\hline $00: 21: 32$ & $\begin{array}{l}\text { VICKY } \\
\text { in } \\
\text { Spanish: } \\
\text { Buenos } \\
\text { días. }\end{array}$ & $\begin{array}{l}\text { Vicky: } \\
\text { Dzień } \\
\text { dobry. }\end{array}$ & $\begin{array}{l}\text { Good } \\
\text { morning. }\end{array}$ & Transfer & Transfer \\
\hline
\end{tabular}

In Table 3, the translation technique used for both elements (replica and multilingual element) coincides. But limiting the analysis to the replica unit might cause an error in identifying the translation technique used to convey the multilingual element in the cases when movies use multilingual elements in the form of single insertions, as shown below in Table 4.

Table 4: Replica - Multilingual element combination in the movie Nine

\begin{tabular}{|c|c|c|c|c|c|}
\hline \multirow{2}{*}{$\begin{array}{l}\text { TCR } \\
\text { original }\end{array}$} & \multirow{2}{*}{$\begin{array}{l}\text { Original } \\
\text { version }\end{array}$} & \multirow{2}{*}{$\begin{array}{l}\text { Polish } \\
\text { version }\end{array}$} & \multirow{2}{*}{$\begin{array}{l}\text { Back } \\
\text { translation }\end{array}$} & \multicolumn{2}{|c|}{ Translation technique } \\
\hline & & & & Replica & $\begin{array}{l}\text { Multilingu } \\
\text { al element }\end{array}$ \\
\hline $00: 06: 27$ & $\begin{array}{l}\text { GUIDO: } \\
\text { We all } \\
\text { have } \\
\text { questions } \\
\text { for Signor } \\
\text { Contini. }\end{array}$ & $\begin{array}{l}\text { GUIDO: } \\
\text { Jak } \\
\text { wszyscy. }\end{array}$ & $\begin{array}{l}\text { GUIDO: } \\
\text { As we all. }\end{array}$ & Paraphrase & Deletion \\
\hline
\end{tabular}

In this example the translation technique used for the replica is the paraphrase. This, however, does not indicate which translation technique was used for the multilingual element (in bold), which in this case was deletion. For this reason, the analysis focuses on two points of view: the macro context (the replica) and the micro context (the multilingual element) as the units of analysis. It is therefore feasible to detect broader potential technique combinations used for L3 elements.

On the other hand, in some cases, replicas seem to be an adequate unit of analysis. In the example from Tarantino's Inglourious Basterds, no distinction is made between the replica and the multilingual elements, as shown in Table 5. 
Table 5: Replica in the movie Inglourious Basterds

\begin{tabular}{|c|c|c|c|c|c|}
\hline \multirow{2}{*}{$\begin{array}{l}\text { TCR } \\
\text { original }\end{array}$} & \multirow{2}{*}{$\begin{array}{l}\text { Original } \\
\text { version }\end{array}$} & \multirow{2}{*}{$\begin{array}{l}\text { Polish } \\
\text { version }\end{array}$} & \multirow{2}{*}{$\begin{array}{l}\text { Back } \\
\text { translation }\end{array}$} & \multicolumn{2}{|c|}{ Translation technique } \\
\hline & & & & Replica & $\begin{array}{l}\text { Multilingual } \\
\text { element }\end{array}$ \\
\hline 00:02:39 & $\begin{array}{l}\text { FARMER in } \\
\text { French } \\
\text { subtitled into } \\
\text { English: } \\
\text { Go back } \\
\text { inside and } \\
\text { shut the } \\
\text { door. }\end{array}$ & $\begin{array}{l}\text { FARMER: } \\
\text { Wracajcie do } \\
\text { domu i } \\
\text { zamknijcie } \\
\text { drzwi. }\end{array}$ & $\begin{array}{l}\text { Go back } \\
\text { inside and } \\
\text { shut the } \\
\text { door. }\end{array}$ & Transfer & Transfer \\
\hline
\end{tabular}

Considering that, in Inglourious Basterds, Tarantino introduces whole conversations in L3, the vast majority of multilingual elements will also be replicas.

\section{Results}

The first stage in the analysis has shown that the use of multilingual elements take a diverse range of forms, from having a very loose and symbolic function to playing a crucial and differentiating role within a movie. The number of occurrences of multilingual elements, although usually strengthening the function, does not necessarily have to be a defining factor. On the one hand, Nine, Vicky Cristina Barcelona and Avatar present a similar number of replicas with L3 elements $(108,103$ and 118 respectively - see Table 6) despite the different implications of multilingualism in these movies. On the other hand, the number of replicas with L3 elements differs significantly in Inglourious Basterds, in which multilingualism plays an essential function. In Tarantino's movie, the number of replicas rises to 570 (Table 6). Only in this case could a directly proportional interdependence between the function of the movie and the number of replicas with implemented multilingual elements be observed.

However, the situation is of a different and more complex nature in the case of the combinations of translation techniques. As already stated, we understand "combination" to be the comparison between the translation technique used to translate the replica and the translation technique used to translate the multilingual element. It seems that the dependence between the function and the range of combinations of translation techniques used is inversely proportional. In the two movies in which the function of multilingualism is clearly marked (Avatar and Inglourious Basterds), only 12 and 8 combinations of translation techniques respectively could be detected. On the other hand, in Nine, 
where multilingualism does not play such an important role, 17 translation technique combinations could be detected. Having said that, in Vicky Cristina Barcelona, which uses multilingualism to maintain the credibility of conversations, 11 translation technique combinations were identified. Table 6 illustrates a detailed distribution of translation technique combinations using numbers of occurrences and percentages.

Table 6: Translation techniques in macro and micro units

\begin{tabular}{|c|c|c|c|c|c|c|c|c|c|}
\hline \multicolumn{2}{|c|}{ Translation technique } & \multicolumn{2}{|c|}{$\begin{array}{l}\text { Nine } \\
108 \\
\text { multilingual } \\
\text { replicas }\end{array}$} & \multicolumn{2}{|c|}{$\begin{array}{l}\text { Vicky } \\
\text { Cristina } \\
\text { Barcelona } \\
103 \\
\text { multilingual } \\
\text { replicas }\end{array}$} & \multicolumn{2}{|c|}{$\begin{array}{l}\text { Avatar } \\
118 \\
\text { multilingual } \\
\text { replicas }\end{array}$} & \multicolumn{2}{|c|}{$\begin{array}{l}\text { Inglorious } \\
\text { Basterds } \\
570 \\
\text { multilingual } \\
\text { replicas }\end{array}$} \\
\hline Macro unit & Micro unit & No. & $\%$ & No. & $\%$ & No. & $\%$ & No. & $\%$ \\
\hline Transfer & Transfer & 25 & 23 & 34 & 33 & 50 & 42 & 382 & 67 \\
\hline Exposition & Exposition & 24 & 22 & 5 & 5 & 13 & 11 & 60 & 10 \\
\hline Condensation & Deletion & 9 & 8 & 2 & 2 & - & - & 1 & 0 \\
\hline Condensation & Transfer & 9 & 8 & 36 & 35 & 2 & 2 & 1 & 0 \\
\hline Transfer & Imitation & 8 & 7 & - & - & - & - & - & - \\
\hline Condensation & Exposition & 7 & 6 & - & - & - & - & - & - \\
\hline Paraphrase & Imitation & 5 & 5 & - & - & - & - & - & - \\
\hline Deletion & Deletion & 4 & 4 & 15 & 14 & 36 & 31 & 10 & 2 \\
\hline Paraphrase & Transfer & 4 & 4 & 2 & 2 & - & - & - & - \\
\hline Condensation & Imitation & 3 & 3 & 1 & 1 & 1 & 1 & - & - \\
\hline Decimation & Deletion & 2 & 2 & - & - & - & - & - & - \\
\hline Transfer & Exposition & 2 & 2 & - & - & - & - & - & - \\
\hline Paraphrase & Deletion & 2 & 2 & - & - & - & - & - & - \\
\hline Transfer & Deletion & 2 & 2 & 1 & 1 & - & - & - & - \\
\hline Imitation & Imitation & 1 & 0 & - & - & - & - & 1 & 0 \\
\hline Decimation & Imitation & 1 & 0 & - & - & - & - & - & - \\
\hline Decimation & Transfer & - & - & 4 & 4 & - & - & - & - \\
\hline Condensation & Condensation & - & - & 1 & 1 & 7 & 6 & 59 & 10 \\
\hline Dislocation & Transfer & - & - & 1 & 1 & - & - & - & - \\
\hline Expansion & Transfer & - & - & - & - & - & - & 14 & 2 \\
\hline Paraphrase & Paraphrase & - & - & - & - & 7 & 6 & 30 & 5 \\
\hline
\end{tabular}




\begin{tabular}{|l|l|l|l|l|l|l|l|l|l|}
\hline Decimation & Exposition & - & - & - & - & 1 & 1 & - & - \\
\hline Decimation & Decimation & - & - & - & - & 1 & 1 & 8 & 1 \\
\hline Dislocation & Dislocation & - & - & 1 & 1 & - & - & 4 & 1 \\
\hline
\end{tabular}

As can be seen in Table 6, a variety of translation technique combinations are used in the four movies. However, if we focus on the column presenting translation techniques used to translate multilingual elements, we can conclude that multilingual elements are subject to a more limited number of translation techniques, namely: transfer, exposition, deletion, imitation, condensation, paraphrasing, and, in rather isolated cases, decimation and dislocation. Since the aim of this paper is to outline the main tendencies in translating multilingual elements in Polish voicedover versions, the analysis will now focus on the most frequently used techniques, that is, transfer, exposition, deletion and imitation.

The most often used combination of techniques is the transfertransfer combination. As has already been mentioned, the technique of transfer consists of the adequate rendering from the original into the translated language (Gottlieb, 1997). It should, however, be noted that, in the case of multilingual movies, the original language is not confined to L1 = English, but might also include L3 elements, as shown in Table 7 (with L3 highlighted in bold).

Table 7: Transfer-transfer combination in the movie Nine

\begin{tabular}{|c|c|c|c|c|c|}
\hline \multirow[t]{2}{*}{$\begin{array}{l}\text { TCR } \\
\text { original }\end{array}$} & \multirow[t]{2}{*}{$\begin{array}{l}\text { Original } \\
\text { version }\end{array}$} & \multirow[t]{2}{*}{ Polish version } & \multirow[t]{2}{*}{$\begin{array}{l}\text { Back } \\
\text { translation }\end{array}$} & \multicolumn{2}{|c|}{$\begin{array}{l}\text { Translation } \\
\text { technique }\end{array}$} \\
\hline & & & & Replica & $\begin{array}{l}\text { Multi- } \\
\text { lingual } \\
\text { element }\end{array}$ \\
\hline 00:06:26 & $\begin{array}{l}\text { JOURNALIST: } \\
\text { Okay, I have } \\
\text { some } \\
\text { questions for } \\
\text { Signor } \\
\text { Contini. }\end{array}$ & $\begin{array}{l}\text { JOURNALIST: } \\
\text { Mam kilka } \\
\text { pytań do pana } \\
\text { Continiego. }\end{array}$ & $\begin{array}{l}\text { JOURNALIST: } \\
\text { I have some } \\
\text { questions to } \\
\text { Mr. Contini. }\end{array}$ & Transfer & Transfer \\
\hline
\end{tabular}

Although the same translation technique appears in both analysis units, the effect in each case is quite different. The use of transfer for replicas seems to be an adequate approach, as it transmits the message faithfully and does not interfere very much with the content of the original. However, in the case of multilingual elements, transfer is an option that deprives the character of his or her identification marker and the exotic flavour in the original. As such, the use of the transfer technique for 
multilingual elements conflicts with the function of the element. The discrepancy seems to be greater in the movies Avatar and Inglourious Basterds, as these movies highlight the importance of multilingualism by introducing subtitles for L3 elements. The Polish version resorts to the voice-over artist, who drowns out the original soundtrack and as a result might impede the correct identification of the character and his or her origin. In Nine, the multilingual elements were directly translated into Polish in more than 35\% of the replicas. In Vicky Cristina Barcelona, the proportion of transferred L3 elements reaches 85\%. In Avatar and Inglourious Basterds, the multilingual elements lost their function in $44 \%$ and $69 \%$ of replicas respectively. Not only do these high percentages suggest that the transfer technique is one of those most commonly used, but they also indicate that multilingual elements and their function are often left out of the translation process.

The omission of multilingual translation might also be used in fast and overlapping dialogues, when the translator is obliged to delete the replica. Having one voice-over artist deliver all the lines imposes inherent limitations on scenes in which several characters are engaged in a dialogue. In this case, the technique of a complete deletion of multilingual elements is mostly applied to elements of less importance. Nevertheless, the multilingual information present in the original version is deleted and does not appear in the translated version, as illustrated in the Table 8 .

Table 8: Deletion-deletion combination in the movie Vicky Cristina Barcelona

\begin{tabular}{|l|l|l|l|l|}
\hline TCR & Original: & Original version: & $\begin{array}{l}\text { Polish } \\
\text { version: }\end{array}$ & \multicolumn{2}{|l|}{ Translation technique } \\
\cline { 4 - 5 } & & Replica & $\begin{array}{l}\text { Multi- } \\
\text { lingual } \\
\text { element }\end{array}$ \\
\hline $00: 21: 38$ & $\begin{array}{l}\text { FATHER in Spanish: } \\
\text { Considera que es tuya. }\end{array}$ & --- & Deletion & Deletion \\
\hline
\end{tabular}

The dialogue between Vicky and Juan's father, who invites the American tourist to his house, has no significant meaning in terms of the plot. It expresses the reality of the situation, however, and tries to represent a credible communication, which is simply removed in the Polish version.

Another translation technique results from the characteristic feature of voice-over that consists of one vocal artist reading the entire dialogue while the original soundtrack is still audible. In many cases, the technique of exposition allows for efficient synchrony between the two soundtracks themselves, thanks to the decision to keep some replicas untranslated but at the same time perfectly audible and understandable to a Polish viewer. This is the case for many replicas in Avatar and 
Inglourious Basterds, where the voice-over artist does not provide any translation but the deleted multilingual replica is in fact a translation of a replica that precedes or follows it, as shown in Table 9.

Table 9: Synchrony between the soundtracks in the movie Inglourious Basterds

\begin{tabular}{|l|l|l|l|l|}
\hline $\begin{array}{l}\text { TCR } \\
\text { original }\end{array}$ & $\begin{array}{l}\text { Original } \\
\text { version }\end{array}$ & Polish version & $\begin{array}{l}\text { Back } \\
\text { translation }\end{array}$ & $\begin{array}{l}\text { Translation } \\
\text { technique } \\
\text { Replica }\end{array}$ \\
\hline $\begin{array}{l}\text { 00:35:13- } \\
\text { 00:35:15 }\end{array}$ & $\begin{array}{l}\text { ALDO: } \\
\text { Now say we } \\
\text { let ya go, and } \\
\text { say you } \\
\text { survive the } \\
\text { war? When } \\
\text { you get back } \\
\text { home, } \\
\text { what'cha } \\
\text { gonna do? }\end{array}$ & $\begin{array}{l}\text { ALDO: } \\
\text { Co zrobisz po jeśli } \\
\text { przeżyjesz? }\end{array}$ & $\begin{array}{l}\text { ALDO: } \\
\text { What are you } \\
\text { going to do } \\
\text { after war if } \\
\text { you survive? }\end{array}$ & Condensation \\
\hline TCR \\
original & $\begin{array}{l}\text { Original } \\
\text { version }\end{array}$ & Polish version & Translation technique \\
\cline { 3 - 5 } & $\begin{array}{l}\text { Replica } \\
\text { WICKI: } \\
\text { Solttest du } \\
\text { den Krieg } \\
\text { uberleben, } \\
\text { was machst } \\
\text { du wenn du } \\
\text { nach Hause } \\
\text { kommst? }\end{array}$ & - & $\begin{array}{l}\text { Multilingual } \\
\text { element }\end{array}$ \\
\hline 00:35:15-35:17 & & Exposition & Exposition \\
\hline
\end{tabular}

In this scene, the character Wicki acts as an interpreter between Aldo and a German soldier. The efficient synchrony in these two fragments maintains the credibility of the scene with no unnecessary repetition. The translation technique applied to the replica itself could be classified as deletion. However, the context in which it occurs allows the original multilingual fragment to be kept audible and understandable. In fact, translating the German fragment would be involve unnecessary repetition from a semantic point of view and, from a pragmatic point of view, it would be a deletion.

The technique of exposition is also used in single insertions of L3 words. The words that are left audible should be familiar to the Polish viewer. For example: "ciao", "maestro" and "grazie" in the movie Nine; "salud", "Buenos días", "gracias" and "sí" in Vicky Cristina Barcelona; and "oui”, "nein", "merci beaucoup" and "Herr" in 
Inglourious Basterds. In the case of Avatar, this approach is not possible because of the nature of the Na'vi language. As Avatar constructs its own artificial language, it is impossible to insert $\mathrm{Na}$ 'vi words, as the condition of comprehension and familiarity would not be fulfilled.

Commonly known words in L3 might also be subject to the imitation technique. In this case, however, the multilingual element is included in the translated soundtrack and is read out by the voice artist. As the imitation technique is limited to only some single words or short expressions such as address forms ("Maestro", "Signor", "Monsignore", "Bambino", "Don" and "Signora") or proper nouns (Piazza Navona, Folies Bergère, Italia and Milano), they were present only in the movie Nine.

Recreating multilingualism can be also observed in the case of the paraphrase and condensation techniques. Both might be applied to longer utterances and not to single words. For this reason, we deal here only with paraphrase and condensation techniques in the movies Avatar and Inglourious Basterds, in which multilingualism is more developed rather than limited to single foreign words. As the techniques of paraphrase and condensation are, in most cases, employed in situations where the macro unit and micro unit coincide, the distinctive function of multilingualism is omitted, as shown below:

Table 10: Paraphrase combination in the movie Inglourious Basterds

\begin{tabular}{|c|c|c|c|c|}
\hline \multirow[t]{2}{*}{$\begin{array}{l}\text { TCR } \\
\text { original }\end{array}$} & \multirow[t]{2}{*}{$\begin{array}{l}\text { Original } \\
\text { version }\end{array}$} & \multirow[t]{2}{*}{$\begin{array}{l}\text { Polish } \\
\text { version }\end{array}$} & \multirow[t]{2}{*}{$\begin{array}{l}\text { Back } \\
\text { translation }\end{array}$} & $\begin{array}{l}\text { Translation } \\
\text { technique }\end{array}$ \\
\hline & & & & $\begin{array}{l}\text { Replica }= \\
\text { multilingual element }\end{array}$ \\
\hline 00:06:35 & $\begin{array}{l}\text { PERRIER in } \\
\text { French: } \\
\text { Vous avez } \\
\text { raison. }\end{array}$ & $\begin{array}{l}\text { PERRIER: } \\
\text { Słusznie. }\end{array}$ & $\begin{array}{l}\text { PERRIER: } \\
\text { That's right. }\end{array}$ & Paraphrase \\
\hline
\end{tabular}

The replica and the multilingual element are the same; the Polish translation has shifted it slightly through the use of paraphrase.

One last technique combination of interest to us is that of expansion-transfer. Although this combination is present only in Inglourious Basterds, it should be noted how translation techniques can change the perspective of the spectator's understanding. As mentioned above, multilingualism fulfils a crucial role in this movie, and this is reflected in the number of dialogues in languages other than English. In order for the viewer to be able to follow the storyline, most of the dialogue is subtitled. Some scenes in German or French, however, are not subtitled. This approach is adopted when one or more characters do not understand the language and the camera is following these characters' 
perspectives. In some cases, the perspective is broken by the Polish version, which delivers translations, as shown in Table 11.

Table 11: Expansion technique in the movie Inglourious Basterds

\begin{tabular}{|c|c|c|c|c|c|}
\hline \multirow{2}{*}{$\begin{array}{l}\mathrm{TCR} \\
\text { original }\end{array}$} & \multirow[t]{2}{*}{ Original version } & \multirow{2}{*}{$\begin{array}{l}\text { Polish } \\
\text { version }\end{array}$} & \multirow{2}{*}{$\begin{array}{l}\text { Back } \\
\text { translation }\end{array}$} & \multicolumn{2}{|c|}{ Translation technique } \\
\hline & & & & Replica & $\begin{array}{l}\text { Multi- } \\
\text { lingual } \\
\text { element }\end{array}$ \\
\hline $00: 41: 26$ & $\begin{array}{l}\text { GERMAN } \\
\text { SOLDIER in } \\
\text { German, no } \\
\text { English translation } \\
\text { provided: Das ist } \\
\text { eine grosse Ehre } \\
\text { Sie } \\
\text { kennenzulernen. } \\
\text { Eine grosse Ehre. }\end{array}$ & $\begin{array}{l}\text { GERMAN } \\
\text { SOLDIER: } \\
\text { To jest } \\
\text { wielki } \\
\text { zaszczyt. }\end{array}$ & $\begin{array}{l}\text { GERMAN } \\
\text { SOLDIER: } \\
\text { It's a great } \\
\text { honor. }\end{array}$ & Expansion & Transfer \\
\hline
\end{tabular}

In this scene, the conversation between Shoshanna and Frederick is interrupted by German soldiers who seem to recognise Frederick and start speaking to him in German, a language Shoshanna does not speak. She tries to figure out what the dialogue is about, and from the context and the behaviour of the soldiers deduces that Frederick is someone famous. In the original version, the viewer sees the scene from Shoshanna's point of view. The Polish spectator receives the translation directly; they therefore adopt Frederick's perspective.

\section{Conclusions and further research}

Apart from the typical limitations that characterise voiced-over translations, the L3 elements in a movie pose an additional challenge for the translator. The introduction of multilingual elements is a very deliberate procedure that is also reflected in the translation. As our analysis shows, multilingualism features a vast range of functions and structures which might be reflected in the number of occurrences of L3 elements. Multilingualism can manifest itself through single words interlaid within the dialogues that should just highlight the origin of the character and some relation to the location, as in the movies Nine and Vicky Cristina Barcelona. It might also be highly developed in order to create a new world in which the language would constitute a differentiating factor between cultures, as in the movie Avatar. Whole dialogues in the newly created artificial language of the $\mathrm{Na}$ 'vi, with its own grammar, phonetics and semantics, are in fact a means to transfer a new culture. Finally, as is the case in Inglourious Basterds, 
multilingualism might be strictly ascribed to character and place. To some extent, multilingualism acts as an independent character within the film, dictating the destiny of the people involved and the progress of events.

To sum up, the aim of this study was to draw up a roadmap of translation techniques used in voice-overs of multilingual movies. It compares the translation techniques which are used to translate multilingual elements and it also analyses the effect(s) that each of them might have. The techniques that most underline the multilingual aspect of a movie are imitation and exposition. Imitation is based on the assumption that spectators understand an L3 element which is simply included in the translated version and read out by the voice-artist. On the other hand, exposition refers to the skilful synchrony between soundtracks. It assumes that spectators base their comprehension not only on the translated soundtrack but also on the original one. Both techniques constitute an efficient tool for recreating the presence of a multilingual environment.

The analysis also showed that, despite the fact that techniques for translating L3 elements do not differ from those used in the case of L1 elements, the effect they can have on multilingual elements might be completely different in some cases. A telling example is the transfer technique which blurs the distinction introduced in the original between L1 and L3 and reduces it to L2. Another technique that erases multilingual elements is deletion. Here, similarly as with L1 elements, the technique omits L3 elements mostly due to limitations imposed by the voice-over mode such as fast overlapping dialogues and one voice-artist reading all the lines.

The findings of this study have a number of implications. First of all, it appears necessary in future research to address the question of the exposition technique first introduced in this paper. This technique highlights the importance of synchrony in the voice-over mode. It shows that two soundtracks might work in parallel and in a complementary way, revealing the multilingual aspect of films. Our findings support claims by Wozniak (2012), who discusses the principles of invisibility and obtrusiveness in voice-over and suggests transforming voice-over into voice-in-between. According to Wozniak (2012), the voice-artist "should deliver the text in pauses and gaps in the original dialogue or - if this is not possible - to reduce the impact by leaving whole sentences or coherent parts of them audible" (p. 216). Such manipulation, as stated in Krzyżaniak (2008), creates the illusion that viewers are listening to the original soundtrack and are able to detect intonation and emotion. Further research regarding the role of the exposition technique, synchrony and perception of multilingual voiced-over movies is required in order to put these hypotheses to the test.

We would also suggest that exposition - defined as a technique that leaves the original soundtrack perfectly audible and understandable could be applicable not only to voice-over but also to subtitling. As in the 
case of voice-over, exposition could be used for commonly known elements whereas comprehension would be based on the original soundtrack only.

Considering the multifaceted nature of multilingualism and the forms it takes, the task of translating multilingual movies for voice-over is undoubtedly not an easy one. Nevertheless, the translator can choose from a large number of translation techniques and combinations to help highlight the multilingualism present in a film.

\section{References}

Aleksonyte, Z. (1999). Comparative analysis of subtitles and voice-over in Danish and Lithuanian respectively as compared to English (based on the Danish Film 'Breaking the Waves'), [term paper]. Vilnus: University of Vilnus.

Baldo, M. (2009). Dubbing multilingual films La terra del ritorno and the ItalianCanadian immigrant experience. InTRAlinea, Special Issue: The Translation of Dialects in Multimedia. Retrieved from: http://www.intralinea.it/

specials/dialectrans/eng_more.php?id=824_0_49_0ISSN 1827-000X

Bartoll, E. (2006). Subtitling multilingual films. Proceedings of the Marie Curie Euroconferences. MuTra: Audiovisual Translation Scenarios, Copenhagen, 15 May 2006. Retrieved from: http://www.euroconferences.info/proceedings/

2006_Proceedings /2006_Bartoll_Eduard.pdf

Bleichenbacher, L. (2008). Multilingualism in the movies: Hollywood characters and their language choices. Tübingen: Francke.

Chaume, F. (2004) Cine y traducción. Madrid: Cátedra.

Corrius i Gimbert, M. (2008). Translating multilingual audiovisual texts: Priorities and restrictions. Applications and implications (Unpublished doctoral dissertation). Autonomous University of de Barcelona.

Corrius, M., \& Zabalbeascoa, P. (2011). Language variation in source texts and their translations: The case of L3 in film translation. Target, 23(1), 113-130.

Delabastita, D., \& Grutman, R. (2005). Introduction. Fictional representatiuons of multilingualism and translation. In: D. Delabastita \& R. Grutman (Eds.), Fictionalising translation and multilingualism. Linguistica Antverpiensia, 4, 11-34.

Franco, E., Matamala, A., \& Orero, P. (2010). Voice-over translation: An Overview. Berna: Peter Lang.

Frommer, P. (Interviewee), \& Matteo M. (Interviewer). (2009). An interview with Paul Frommer, alien language creator for Avatar [Interview transcript]. Retrieved from Unidentified Sound Object Web site: http://

usoproject.blogspot.com.es/2009/11/interview-with-paul-frommer-alien.html.

Garcarz, M. (2007). Przekład slangu w filmie: Telewizyjne przekłady filmów amerykański na język polski. Cracow: Tertium.

Gottlieb, H. (1997). Subtitles, translation and idioms (Doctoral dissertation). Copenhagen: University of Copenhagen. 
Grigaraviciute, I., \& Gottlieb, H. (1999). Danish voices, Lithuanian voice-over. The mechanics of non-synchronous translation, Perspectives: Studies in Translatology 7 (1), 41-80.

Grutman, R. (1998). Multilingualism and translation. In M. Baker (Ed.), Routledge encyclopedia of translation studies. (pp. 157-160). London: Routledge.

Heiss, C. (2004). Dubbing multilingual films: A new challenge? Meta: Translators' Journal, 49(1), 208-220.

Krzyżaniak, W. (2008, January 11). Głosy z ekranu. Gazeta Wyborcza. Gazeta Telewizyjna, p. 6.

Martins, H. (2005). Code-switching in US Ethnic Literature: Multiple perspectives presented through multiple languages. Changing English, 12(3), 403-415.

Meylaerts, R. (2006). Heterolingualism in/and translation: How legitimate is the other and his/her language?: An introduction. Target 18(1), 1-15.

Molina, L., \& Hurtado Albir, A. (2002). Translation techniques revisited: A dynamic and functionalist approach. Meta: Translators' Journal, 47(4), 498-512.

Merino Álvarez, R. (1994). Traducción, tradición y manipulación: Teatro inglés en España, 1950-1990. León: Universidad de León / Lejona, Universidad del País Vasco.

Orero, P. (2006). Synchronization in Voice-Over. In J. P. Bravo Gozalo (Eds.), Aspects of Translation (pp. 255-264). Valladolid: Universidad de Valladolid.

O’Sullivan, C. (2011). Translating popular film. Basingstoke: Palgrave Macmillan.

Romero Ramos, L. (2010). Un estudio descriptivo sobre la traducción de la variación lingüística en los medios audiovisuales (doblaje y subtitulación): Las traducciones de Il Postino (Unpublished doctoral dissertation).Autonomous University of Barcelona.

Skuggevik, E. (2009). A typological threesome: Subtitling, interpretation and voiceover. A study of symbiotic translation types, In: Ł. Bogucki \& K. Kredens (Eds.), Perspectives on audiovisual translation (pp. 13-26). Frankfurt: Peter Lang.

Tarantino Blends Humor, Carnage Again In 'Basterds. (2009, August 21). NPR. Retrieved

from: http://www.npr.org/templates/story/story.php?storyId=112085605

Wahl, C. (2005). Discovering a Genre: The Polyglot Film. Cinemascope Independent Film Journal, 1. Retrieved from www.cinema-scope.net

Woźniak, M. (2012). Voice-over or Voice-in-between? Some Considerations about the Voice-over Translation of Feature Films on Polish Television. In A. Remael, P. Orero, \& M. Carroll (Eds.), Audiovisual Translation and Media Accessibility at the Crossroads. Media for All 3 (pp. 209-228). Amsterdam, New York, NY: Rodopi.

Vicky Cristina Barcelona (2009). Filmweb.pl. Retrieved from: http://www.filmweb.pl/film/Vicky+Cristina+Barcelona-2008-405077. 


\section{Filmography}

Allen, Woody. (2009). Vicky, Cristina, Barcelona (Vicky, Cristina, Barcelona). [Movie picture]. United States, Spain: Kino Świat.

Cameron, James. (2009). Avatar (Avatar) [Movie picture]. United States: $20^{\text {th }}$ Century Fox.

Marshall, Rob (Director \& Producer). (2009). Dziewięć (Nine) [Movie picture]. United States: Kino Świat.

Tarantino, Quentin. (2009). Bękarty wojny (Inglourious Basterds). [Movie picture]. United States, Germany: Universal Studio.

This article is a part of a $\mathrm{PhD}$ at the Department of Translation and Interpreting and East Asian Studies at the Autonomous University of Barcelona. It has never been published before in any form. It is also part of the project "Linguistic and sensorial accessibility: technologies for voiceover and audio description", funded by the Spanish Ministry of Economy and Competitiveness (FFI2012-31023). 